NOTA

\title{
First record on an amphibian in the canopy of temperate rainforests of southern South America: Eupsophus calcaratus (Cycloramphidae)
}

\author{
Primer registro de un anfibio en el dosel del bosque templado del sur \\ de Sudamérica: Eupsophus calcaratus (Cycloramphidae) \\ Iván A Díaz ${ }^{\mathrm{ab} * \text {, Claudio Correa }}{ }^{\mathrm{c}}$, Maurice E Peña-Foxon ${ }^{\mathrm{b}}$, Marco A Méndez ${ }^{\mathrm{c}}$, Andrés Charrier \\ *Corresponding author: aUniversidad Austral de Chile, Facultad de Ciencias Forestales y Recursos Naturales, Instituto \\ de Silvicultura, casilla 567, Valdivia, Chile, tel.: 56-63-293026, fax: 56-63-221230, ivan.diaz@ docentes.uach.cl \\ bFundación Senda Darwin, Chiloé, Chile. \\ 'Universidad de Chile, Facultad de Ciencias, Laboratorio de Genética y Evolución, Santiago, Chile.
}

\section{SUMMARY}

\begin{abstract}
We record for the first time arboreal habits in amphibians from the temperate rainforests of southern South America. In April 2006 we collected an individual of Eupsophus calcaratus at $16 \mathrm{~m}$ height, in a large Eucryphia cordifolia tree of old-growth forest of Chiloé Island, southern Chile. This species was considered until now as a terrestrial species, and the similarities between forest ground and epiphytic layer may allow this species inhabit the canopy. However, the level of association among these frogs and the forest canopy is unknown. The canopy of southern South America forests remains barely known, and as other forest canopies, may support high species diversity.
\end{abstract}

Key words: arboreal frogs, forest canopy, Chiloé temperate rainforest.

\section{RESUMEN}

Este es el primer registro de hábitos arbóreos en una especie de anfibio de los bosques templados del sur de Sudamérica. En abril de 2006 fue colectado un individuo de Eupsophus calcaratus a $16 \mathrm{~m}$ de altura, en un gran árbol de la especie Eucryphia cordifolia en bosques antiguos de la Isla de Chiloé. Hasta ahora, esta especie era considerada como un animal terrestre. Similitudes entre el material epifito y el piso del bosque podrían permitir que esta especie habite en el dosel del bosque, aunque el nivel de asociación entre esta especie y el dosel aún no se conoce. El dosel de los bosques de Sudamérica es escasamente explorado y, tal como ocurre en otros ecosistemas forestales, podría albergar una gran riqueza de especies.

Palabras clave: sapos arbóreos, dosel del bosque, bosques templados de Chiloé.

\section{INTRODUCTION}

The temperate rainforests of South America (STF) are mainly distributed in Chile and westernmost Argentina, and represent a biogeographical island separated from other forest ecosystems by over $1500 \mathrm{~km}$ of geographical barriers (the Andes and the Atacama and Patagonia deserts) during more than 1.5 million years (Armesto et al. 1998). This long term isolation has caused a high percentage of endemism in many taxa (Villagrán and Hinojosa 1997, Armesto et al. 1998), including the $80 \%$ of the amphibian species (Formas 1979, Armesto et al. 1996). The amphibians of STF belong to the families Bufonidae, Calyptocephalellidae, Ceratophryidae, Cycloramphidae and Leiuperidae, with most species considered as terrestrial, associated to a variety of habitats including swamps, ravines, shrubs and forest ground in old-growth and secondary forests (Cei 1962, Méndez et al. 2005, Rabanal and Núñez 2008).

Arboreal frogs are frequent in northern temperate rainforests and reach a high diversity in tropical forests (Duellman and Trueb 1994). However, frogs with arboreal habits have not been recorded in STF (Formas 1979). Cei (1962) suggested arboreal habits based on anatomical criteria for the endemic STF genera Batrachyla and Hylorina, but these species have been observed on the ground and only up to four meters above, in trees, bushes or stumps (Busse 1971, Formas 1979). In this note, we document the first record of arboreal habits in the terrestrial Eupsophus calcaratus (Günther 1881) frog, from old-growth forest of southern temperate rainforests of Chiloé Island, southern Chile. 


\section{METHODS}

The study area was located in the north west of Chiloé Island, at Punta Huechucuicui ( $41^{\circ} 47^{\prime}$ S, $74^{\circ} 00^{\prime}$ W). This area is characterized by a hilly landscape, with a large fragment of 300 ha of undisturbed and unpolluted old-growth temperate rainforest, surrounded by extensive forests with different degrees of human disturbance, completing a total area of around one thousand ha. Forests are dominated by broad-leaved evergreen trees, with scattered emergent trees of Eucryphia cordifolia Cav. (Monimiaceae) and a canopy dominated by Laureliopsis philippiana Mol. (Monimiaceae), Aextoxicon punctatum R. et P. (Aextoxicaceae), Amomyrtus luma Mol. (Myrtaceae), A. meli (Phil.) Legr. et Kaus. (Myrtaceae) and Luma apiculata (DC.) Burret (Myrtaceae). Climate is temperate with oceanic influence (DiCastri and Hajek 1976). The nearest meteorological station in Punta Corona $\left(41^{\circ} 47^{\prime} \mathrm{S}, 73^{\circ} 52^{\prime} \mathrm{W}\right)$ has an annual average of $2,444 \mathrm{~mm}$ of rainfall and a mean annual temperature of $10.7^{\circ} \mathrm{C}$.

In this area, we acceded to the canopy of a large E. cordifolia tree $30 \mathrm{~m}$ tall and $1.3 \mathrm{~m}$ diameter at breast height (Díaz et al. 2010). Large E. cordifolia trees are usually densely covered by epiphytes, including Gesneriaceae such as Sarmienta scandens (Brandis) Seeman, Bromeliaceae such as Fascicularia bicolor (Ruiz et Pav.) Mez, many species of ferns and mosses and the hemi-epiphytic tree Raukaua laetevirens (Gay) Franche (Gutiérrez et al. 2008, Díaz et al. 2010). This tree was climbed using ropes and arborist techniques following the protocols described by the Tree Climbing USA (2006). Traps for invertebrates were located on the tree crown, as a part of a larger study of canopy biodiversity in this forest (Díaz 2009). Two eclector traps designed for the capture of walking invertebrates (Basset et al. 1997) were located at $16 \mathrm{~m}$ above the ground. Invertebrate surveys were monthly conducted during three to four days per month, extending the survey for over a year from March 2006 to May 2007. During March and April 2006 the traps were filled with alcohol $70 \%$, but since May 2006, alcohol was not used anymore and a capsule of Diazinon was located instead, a dry poison which unlike alcohol, does not damage flying insects such as moths.

The identity of the amphibian specimen found was defined comparing a fragment of the mitochondrial gen $16 \mathrm{~S}$ with available sequences at GenBank. Total DNA was extracted using a salt method, from a finger fragment from the posterior right leg. Primers used, PCR protocol and sequence editing, were described in Correa et al. (2006). Comparison was conducted using BLAST (Basic Local Alignment Search Tool) from the National Center for Biotechnology Information (2009).

\section{RESULTS}

In April 2006, during the austral fall an individual of Eupsophus calcaratus was captured in an Eclector trap filled with alcohol. The individual was probably an adult (snout-vent length $=31 \mathrm{~mm}$ ), and was deposited in the Herpetological Collection of the Departamento de Biología Celular y Genética of Universidad de Chile (DBGUCH), with collection number 0604056 (figure 1). The genetic sequence showed the highest level of identity $(98.3 \%, 535$ nucleotides compared) with the gene $16 \mathrm{~S}$ of Eupsophus calcaratus (access number DQ864552).

\section{DISCUSSION}

Arboreal frogs are very common in tropical forests from the Neotropical Region (e.g. families Centrolenidae and Hylidae) and in the North American temperate forests, where the family Hylidae is also present (Duellman and Trueb 1994). However, arboreal habits for frogs in STF
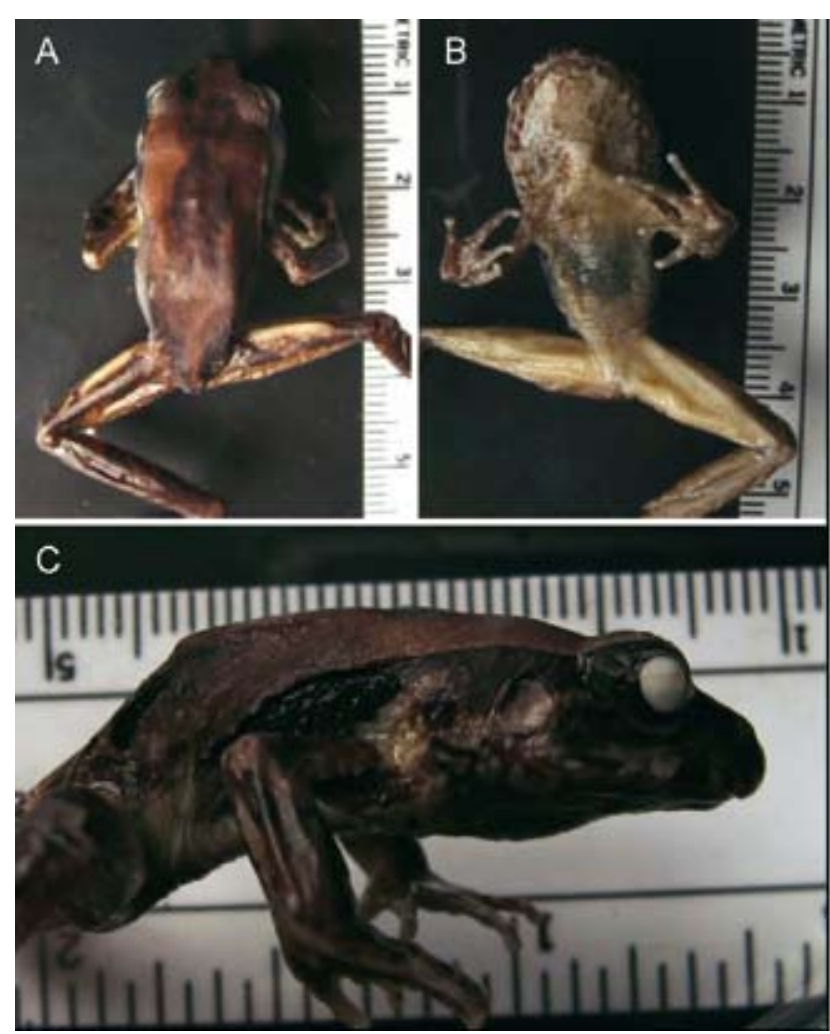

Figure 1. Individual of Eupsophus calcaratus collected at $16 \mathrm{~m}$ height in the canopy of a large Eucryphia cordifolia tree in Chiloé Island, southern Chile. (A) Dorsal view, (B) ventral view, (C) lateral view.

Individuo de Eupsophus calcaratus colectado a $16 \mathrm{~m}$ en el dosel de un gran árbol de la especie Eucryphia cordifolia en la Isla de Chiloé, Chile. (A) Vista dorsal, (B) vista ventral, (C) vista lateral. 
have not been recorded before. Several authors describe climbing habits in Batrachyla leptopus (Bell) and Hylorina sylvatica Bell (Cei 1962, Busse 1971, Formas 1979), but most observations were recorded less than three or four meters from ground level. Concerning the particular case of Eupsophus, this genus is endemic from STF (Formas 1995 ) and presents a large geographical distribution from $36^{\circ} \mathrm{S}$ to $50^{\circ} \mathrm{S}$ (Méndez et al. 2005); all known species are strongly associated with the forest ground, living below logs and under rocks in small ravines (Cei 1962, Ortiz and Ibarra-Vidal 2005). For Chiloé Island only two Eupsophus species have been reported: E. calcaratus and E. emiliopugini (Rabanal and Núñez 2008, IUCN 2009). The species Eupsophus calcaratus is considered a common species, that reproduce on the ground, where the female deposits the eggs covered by a protective mucosity, and the development of the embryos is triggered by pond inundation (Formas and Vera 1980). The male presents parental care behavior, and after the laying, the male remains by the clutch, and later on also by the tadpoles, in small ponds in the ground (Úbeda and Nuñez 2006). Tadpoles develop quickly, with structures that keep their larval condition beyond the end of larval life (Vera Candioti et al. 2005).

In the canopy of old-growth forest of Chiloé Island, trees are evergreen and densely covered by epiphytes, resembling tropical forests. Large trees present a big and straight trunk and a crown that can overtake the forest canopy. Trunks and large branches present many small cavities, sometimes filled with water, and are densely covered by a large number of epiphytes reaching over $500 \mathrm{~kg}$ fresh weigh, mostly organic detritus (Díaz et al. 2010). The organic detritus of the epiphytic layer presented similarities with the organic horizon of the forest soil (Pérez et al. 2005), and may permit the survival of frogs in the canopy. There, holes filled with water are frequent in branches, and can represent similar habitats for egg laying than do inundated ponds at the ground level. Also, vegetation composed by vines and bromeliads create an heterogeneous habitat where frogs can hide and live, and conduct part of their life cycle.

Canopy environment has been little explored in STF, and arboreal habits of forest frogs have not been studied. During our investigations, big clumps of epiphytes from two $E$. cordifolia trees were removed and let fall onto the ground (Díaz et al. 2010). Less than an hour after epiphyte removal, we observed several individuals of $E$. calcaratus walking on the forest floor, near removed epiphyte clumps. This observation, along with the captured individual at $16 \mathrm{~m}$ reported here, makes us suspect the presence of $E$. calcaratus in the canopy could be frequent. In support to our findings, one recent discovery of eggs of Batrachyla leptopus in a tree at $13 \mathrm{~m}$ height provides strong evidence of the arboreal habits in this frog species ${ }^{1}$. All these observations suggest that frogs are present in forest canopies of southern temperate rainforest; however, the diversity, abundance, reproductive habits, and the strength of the association between frogs and tree crowns remain unknown. The canopy of southern South America forests remains barely known and, as well as other forest canopies, may support high species diversity.

\section{ACKNOWLEDGEMENTS}

We are very grateful to Ms. Katia Velázquez, Mr. Javier de la Calle, and to the family Velázquez-Martínez for their generosity in providing access and housing in the study area. We thank especially the support of Dr. Juan J Armesto for all the facilities provided for both, laboratory and field work. We also thank Ana María Venegas and Camila Tejo for their field assistance, Wara Marcelo for his permanent encouragement and support, Dr. Kathryn E Sieving for providing valuable comments to the manuscript, and two anonymous reviewers who also provided valuable comments. This is a contribution of the research program of Senda Darwin Foundation, Chile to the knowledge of the southern temperate rainforests. This study was funded by FONDECYT 1050225, The Canon National Parks Science Scholars Program, and CONICYT PDA-24 endowed to Dr. Antonio Lara, Universidad Austral de Chile. C Correa acknowledges the support of a CONICYT doctoral fellowship.

\section{REFERENCES}

Armesto JJ, R Rozzi, P León-Lobos. 1996. Ecología de los bosques chilenos: síntesis y proyecciones. In Armesto JJ, C Villagrán, MTK Arroyo eds. Ecología de los bosques nativos de Chile. Santiago, Chile. Universitaria. p. 405-421.

Armesto JJ, R Rozzi, C Smith-Ramírez, MTK Arroyo. 1998. Conservation targets in South-American temperate forests. Science 282: 1271-1272.

Basset Y, ND Springate, HP Aberlenc, G Delvare. 1997. A review of methods for sampling arthropods in tree canopies. In Stork NE, J Adis, RK Didham eds. Canopy arthropods. London, United Kingdom. Chapman \& Hall. p. 27-52.

Busse K. 1971. Desarrollo de Batrachyla leptopus Bell con observaciones sobre su ecología y comportamiento (Amphibia; Leptodactylidae). Investigaciones Zoológicas Chilenas 15: 5-63.

F Osorio and F Rabanal: F Osorio is an undergraduate student in Biological Sciences, Science Faculty, Universidad Austral de Chile. F Rabanal is a Doctoral Student in the Zoology Institute, Universidad Austral de Chile. Personal communication. 
Cei JM. 1962. Batracios de Chile. Santiago, Chile. Ediciones de la Universidad de Chile. 128 p.

Correa C, A Veloso, P Iturra, MA Méndez. 2006. Phylogenetic relationships of Chilean leptodactylids: a molecular approach based on mitochondrial genes $12 \mathrm{~S}$ and 16S. Revista Chilena de Historia Natural 79: 435-450.

Díaz IA. 2009. Linking composition, structure and functions of biodiversity: relationships among epiphytes, invertebrates and birds in the canopy of Chilean temperate rainforests. $\mathrm{Ph}$. D. dissertation. Gainesville, Florida, USA. University of Florida. 168 p.

Díaz IA, KE Sieving, ME Peña-Foxon, J Larraín, JJ Armesto. 2010. Epiphyte Diversity and biomass loads of canopy emergent trees in Chilean temperate rainforests: A neglected functional component. Forest Ecology and Management 259: 1490-1501.

Di Castri F, ER Hajek. 1976. Bioclimatología de Chile. Santiago, Chile. Ediciones de la Universidad Católica de Chile. 156 p.

Duellman W, L Trueb. 1994. Biology of Amphibians. London, United Kingdom. The Johns Hopkins University Press. 670 p.

Formas JR. 1979. La herpetofauna de los bosques temperados de Sudamérica. In Duellman W. ed. The South America herpetofauna: its origin, evolution and dispersal. Monograph 7. Lawrence, Kansas, USA. Museum of Natural History, University of Kansas. p. 341-369.

Formas JR. 1995. Anfibios. In Simonetti JA, MTK Arroyo, AE Spotorno, E. Lozada eds. Diversidad biológica de Chile. Santiago, Chile. CONICYT. p. 314-335.

Formas JR, MA Vera. 1980. Reproductive patterns of Eupsophus roseus and E. vittatus. Journal of Herpetology 14: 11-14.

Gutiérrez AG, JC Aravena, NV Carrasco-Farías, DA Christie, M Fuentes, JJ Armesto. 2008. Gap-phase dynamics and coexistence of a long-lived pioneer and shade-tolerant tree species in the canopy of an old-growth coastal temperate rain forest of Chiloé Island, Chile. Journal of Biogeography 35: 1674-1687.
IUCN (International Union for Conservation of Nature, $\mathrm{CH}$ ) 2009. IUCN Red List of Threatened Species. Version 2009.1. Accessed on Sep. 01 2009. Available at www. iucnredlist.org.

Méndez MA, ER Soto, F Torres-Pérez, A Veloso. 2005. Anfibios y reptiles de los bosques de la Cordillera de la Costa (X Región, Chile). In Smith-Ramírez C, JJ Armesto, C Valdovinos eds. Historia, biodiversidad y ecología de los bosques costeros de Chile. Santiago, Chile. Universitaria. p. 441-455.

National Center for Biotechnology Information. 2009. Basic Local Alignment Search Tool. Accessed on jul. 2009. Available at http://blast.ncbi.nlm.nih.gov.

Ortiz JC, H Ibarra-Vidal. 2005. Anfibios y reptiles de la cordillera de Nahuelbuta. In Smith-Ramírez C, JJ Armesto, $\mathrm{C}$ Valdovinos eds. Historia, biodiversidad y ecología de los bosques costeros de Chile. Santiago, Chile. Universitaria. p. 427-440.

Pérez CA, R Guevara, MR Carmona, JJ Armesto. 2005. Nitrogen mineralization in epiphytic soils of an old-growth Fitzroya cupressoides forest, southern Chile. Ecoscience 12: 210-215.

Rabanal FE, JJ Núñez. 2008. Anfibios de los bosques templados de Chile. Valdivia, Chile. Universidad Austral de Chile. $206 \mathrm{p}$.

Tree Climbing USA. 2006. Tree Climbing USA. Accessed on Feb. 01 2006. Available at www.treeclimbingusa.com.

Úbeda CA, JJ Núñez. 2006. New parental care behaviours in two telmatobiine genera from temperate Patagonian forests: Batrachyla and Eupsophus (Anura: Leptodactylidae). Amphibia-Reptilia 27: 441-444.

Vera Candioti MF, C Úbeda, EO Lavilla. 2005. Morphology and metamorphosis of Eupsophus calcaratus tadpoles (Anura: Leptodactylidae). Journal of Morphology 264: 161-177.

Villagrán C, LF Hinojosa. 1997. Historia de los bosques del sur de Sudamérica, II: Análisis fitogeográfico. Revista Chilena de Historia Natural 70: 241-267.

Recibido: 09.09.09

Aceptado: 05.04.10 